\title{
Effect of prenatal and postnatal photoperiod on spermatogenic development in the Djungarian hamster (Phodopus sungorus sungorus)
}

\author{
L. H. van Haaster ${ }^{1}$, F. J. C. M. van Eerdenburg ${ }^{2}$ and D. G. de Rooij ${ }^{1}$ \\ ${ }^{\mathrm{I}}$ Department of Cell Biology, Medical School, Utrecht University, Utrecht. The Netherlands; and \\ ${ }^{2}$ Department of Functional Morphology, Veterinary School, Utrecht University, Utrecht,
}

The Netherlands

\begin{abstract}
The effect of the pre- and postnatal daylength on the start of spermatogenesis and further testicular development from day 4 up to day 127 was investigated in Djungarian hamsters. Hamsters were either gestated under long ( $16 \mathrm{~h}$ light: $8 \mathrm{~h}$ dark) photoperiod and reared under long or short ( $4 \mathrm{~h}$ light: $20 \mathrm{~h}$ dark) photoperiod after birth (L/L and L/S hamsters, respectively), or gestated under short photoperiod and transferred to long photoperiod after birth (S/L hamsters). In $\mathrm{L} / \mathrm{L}$ and $\mathrm{L} / \mathrm{S}$ hamsters, spermatogenesis started between day 4 and day 5 (day of birth $=$ day 1 ), when the first gonocytes entered the S-phase. A, Intermediate and B spermatogonia were first observed on days 6,8 and 9, respectively. The proliferation pattern of gonocytes and Sertoli cells, studied between day 4 and day 9 , did not differ between L/L and L/S hamsters. Hence, the duration of the postnatal photoperiod had no effect on the start of spermatogenesis. The first effect of postnatal photoperiod on spermatogenic development was observed on day 15, when testis weights and tubular diameters were reduced in L/S animals. From day 22 onwards, spermatogenesis was arrested mainly at the mid-pachytene stage, no tubular lumen was formed, and the number of preleptotene spermatocytes was reduced. The ultimate number of Sertoli cells per testis was not affected by postnatal short photoperiod. The duration of the prenatal photoperiod had a clear effect on spermatogenesis after birth. In $\mathrm{S} / \mathrm{L}$ hamsters, the number of gonocytes per tubular cross-section was reduced on day 4 and 4.5. Gonocyte proliferation was reduced on day 5 and spermatogenesis started one day later. Consequently, A and Intermediate spermatogonia appeared on day 7 and 9 , respectively. Sertoli cell proliferation was also shifted to later ages, but the ultimate number of Sertoli cells did not differ from L/L or L/S hamsters. From day 29 onwards, the number of preleptotene spermatocytes was increased in S/L hamsters, indicating that the Sertoli cells in these animals could support more germinal cells. In conclusion, a short postnatal photoperiod does not affect spermatogenesis before day 15 after birth, when further testicular development becomes arrested. A short prenatal photoperiod delays the start of spermatogenesis by one day, alters the proliferation pattern of Sertoli cells, and from day 29 onwards, enables the Sertoli cells to support more germinal cells. The duration of the pre- and postnatal photoperiod did not affect the ultimate number of Sertoli cells.
\end{abstract}

\section{Introduction}

The start of spermatogenesis is the time at which gonocytes are stimulated to form A spermatogonia. In rodents spermatogenesis starts within the first week of life. If the day of birth is considered as day 1 , spermatogenesis starts in the rat on day 4 (Hilscher and Makoski, 1968), in the mouse on day 1 (Kluin and De Rooij, 1981) or on day 3 (Sapsford, 1962), probably depending upon strain differences, and in the golden hamster on day 7 (Miething, 1989).

It is not known how the start of spermatogenesis is regulated, but gonadotrophins may play a role. Follicle-stimulating hormone (FSH) has been shown to stimulate the proliferation of

Received 28 February 1992 gonocytes (Almirón and Chemes, 1988). In addition, Steinberger (1967) has shown that spermatogenesis in vitro, in a chemically defined medium, proceeds more efficiently from A spermatogonia than from gonocytes. It was suggested that the start of spermatogenesis is under some hormonal control. However, daily administration after birth of oestradiol benzoate or testosterone propionate, which decreases gonadotrophins to undetectable values, did not inhibit the start of spermatogenesis (Steinberger and Duckett, 1965; Chowdhury and Steinberger, 1975).

Spermatogenesis in adult Djungarian hamsters is under control of daylength: exposure to short photoperiod induces testicular regression (Figala et al., 1973; Hoffmann, 1973). It has been suggested that spermatogenesis in Djungarian hamsters, reared under short photoperiod, does not start until about 130 
days of age (Hoffmann, 1978). Other studies have shown that Djungarian hamsters reared under long or short photoperiod exhibit the same increase in testis weight up to 15 days of age, suggesting that the start of spermatogenesis is not influenced by the duration of the photoperiod (Yellon and Goldman, 1984; Pratt and Goldman, 1986). In addition to the duration of the photoperiod after birth, the prenatal photoperiod also has an effect on testicular development in Djungarian hamsters. Stetson $e t$ al. (1986) found increased testis weights at 28 and 34 days of age in Djungarian hamsters gestated under short photoperiod and reared under long photoperiod. It has been shown that before birth the information about the duration of the photoperiod is transferred to the fetus by maternal melatonin (Weaver and Reppert, 1986; Stetson et al., 1989; Horton et al., 1989).

These studies have made it clear that the Djungarian hamster is an excellent model for studying the influence of environment on sexual development, as this species responds to both prenatal and postnatal daylength. We performed a detailed study to determine the effects of long and short photoperiod, before and after birth, on the start of spermatogenesis and subsequent spermatogenic development in Djungarian hamsters.

\section{Materials and methods}

\section{Animals}

Djungarian hamsters (Phodopus sungorus sungorus) were born in our laboratory breeding colony (supplied by P. Niklowitz, Max Planck Clinical Research Unit for Reproductive Medicine, Münster). Three different light regimens were used: (i) $16 \mathrm{~h}$ light: $8 \mathrm{~h}$ dark (lights on from 02.00 to $18.00 \mathrm{~h}$ ) before and after birth (L/L hamsters); (ii) $16 \mathrm{~h}$ light: $8 \mathrm{~h}$ dark before birth and $4 \mathrm{~h}$ light: $20 \mathrm{~h}$ dark (lights on from 13.00 to $17.00 \mathrm{~h}$ ) after birth (L/S hamsters); and (iii) $4 \mathrm{~h}$ light:20 h dark before birth and $16 \mathrm{~h}$ light: $8 \mathrm{~h}$ dark after birth ( $\mathrm{S} / \mathrm{L}$ hamsters). The day of birth was designated as day 1. Pups were weaned at 3 weeks of age and housed under long or short photoperiod until the appropriate age.

The number of animals in the 4-9-day-old experimental groups varied from four to eight per group. In these studies, each group was composed of animals from at least three different litters. In the disector study, four animals derived from four different litters were used per group. In the 15-127-dayold groups four to eleven animals per group were used. The breeding colony was checked for litters once a day. Only newborn litters, identified by their complete lack of hair, were used for the groups of animals studied at days 4-9. Animals born the previous day had some hair and were assigned to the 15-127-day-old groups.

\section{Tissue preparation}

Two hours before they were killed 4-9-day-old hamsters received a s.c. injection of $150 \mathrm{mg}$ bromodeoxyuridine $\mathrm{kg}^{-1}$ (BrdU, Sigma, St Louis). BrdU is incorporated into the DNA of S-phase cells and can be made visible by means of immunocytochemistry. Body and testis weights were measured and one testis was fixed in Bouin's fluid for $18-24 \mathrm{~h}$ and the other in Carnoy's fluid for $1.5 \mathrm{~h}$. The testes were embedded in glycol methacrylate/butanediolmonoacrylate (GMA/BA, BDH Limited, Poole, Dorset; Polysciences Inc., Warrington) according to Van Goor et al. (1988) at a ratio of 85:15.

\section{Histology}

Sections of $5 \mu \mathrm{m}$ of the testes fixed in Bouin's fluid were stained with the periodic acid-Schiff (PAS) technique and Gill's haematoxylin. In these sections, testicular morphology was studied, and tubular diameters, the numbers of preleptotene spermatocytes and the frequency of the most advanced cell type were determined. For the disector method, sections of $3 \mu \mathrm{m}$ of $\mathrm{L} / \mathrm{L}$ and $\mathrm{S} / \mathrm{L}$ testes were used. $\mathrm{L} / \mathrm{S}$ testes were sectioned at $1 \mu \mathrm{m}$, since Sertoli cell shrinkage in $\mathrm{L} / \mathrm{S}$ testes meant that it was impossible to count Sertoli cells in $3 \mu \mathrm{m}$ sections. Sections of $3 \mu \mathrm{m}$ of the testes fixed in Carnoy's fluid were used to visualize the BrdU with monoclonal anti-BrdU and peroxidase conjugated rabbit anti-mouse antibodies followed by a diaminobenzidine $-\mathrm{H}_{2} \mathrm{O}_{2}$ reaction, according to Harms et al. (1986) and Van de Kant et al. (1990). In these sections, the labelling index of gonocytes and Sertoli cells, the mitotic index of gonocytes and the number of gonocytes per cross-section were counted.

\section{Morphological analysis}

Gonocytes were identified using the criteria described previously (Kluin and De Rooij, 1981). The 12 stages of the cycle of the seminiferous epithelium were identified using the criteria described for the Chinese hamster (Oud and De Rooij, 1977).

The number of gonocytes per tubular cross-section was determined by examining at least 100 tubular cross-sections per animal. The mitotic index of gonocytes and labelling index of gonocytes and Sertoli cells were determined by counting at least 500 gonocytes and 500 Sertoli cells per animal. The labelling and mitotic index were defined as the fraction of the cells that had incorporated BrdU or were in mitosis, respectively.

The most advanced cell types were identified in at least 100 tubular cross-sections per animal and expressed as a percentage of the total number of cross-sections studied. The average tubular diameter was determined by measuring 30 diameters per animal. The smallest diameter of each tubular cross-section through the centre of the tubule was measured. The percentage of tubular cross-sections containing a lumen at $\mathbf{1 5}$ days of age was determined by studying at least 100 cross-sections per animal.

At least 500 Sertoli cell nucleoli per animal were counted to obtain the number of preleptotene spermatocytes per 1000 Sertoli cell nucleoli. The crude counts of Sertoli cell nucleoli and preleptotene spermatocytes were corrected for shrinkage of Sertoli cell nucleoli and section thickness according to Abercrombie (1946). The diameter of Sertoli cell nucleoli was measured by means of image analysis. For each animal, an average diameter of 30 Sertoli cell nucleoli was determined. The diameter of the preleptotene spermatocytes was not influenced by the length of the photoperiod or the age of the animals. An average diameter calculated from 10 randomly chosen animals 

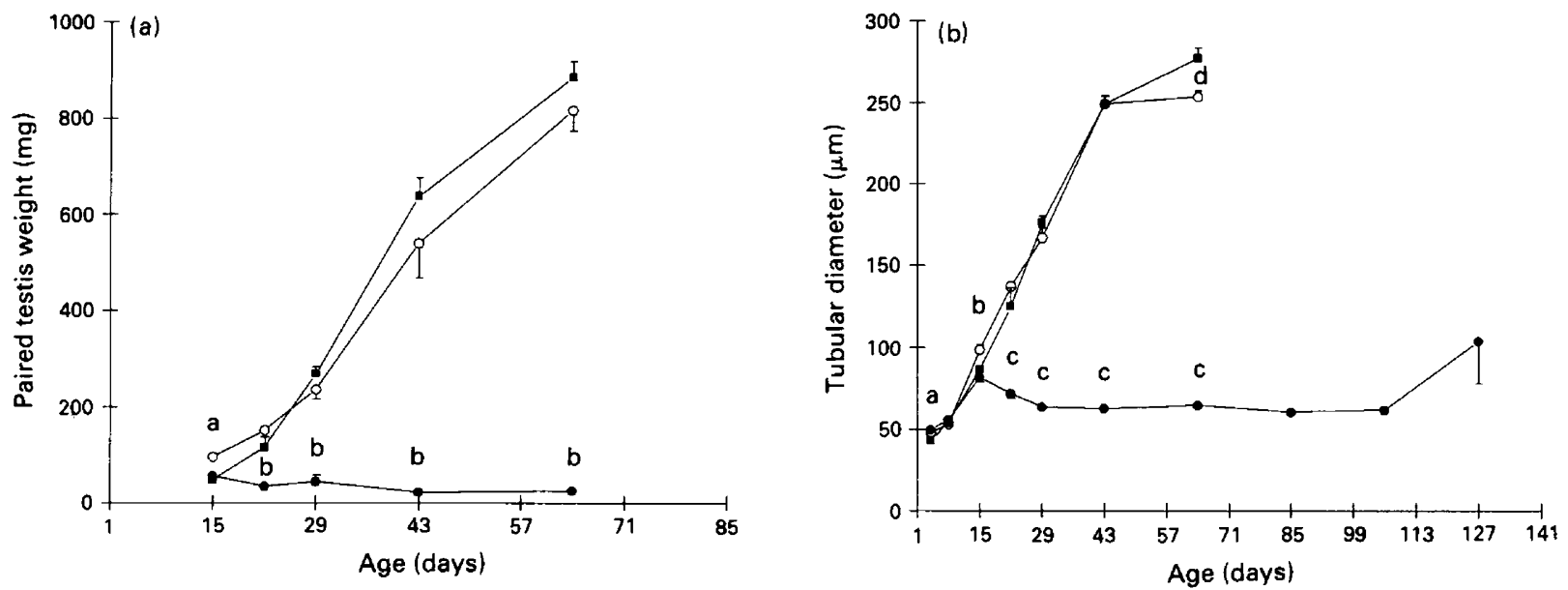

Fig. 1. Testis weights and tubular diameters of $(O) \mathrm{L} / \mathrm{L},(\mathbf{)}) \mathrm{L} / \mathrm{S}$ and $(\boldsymbol{\square}) \mathrm{S} / \mathrm{L}$ hamsters $(n=4-11)$. The vertical bars represent the SEM. The SEM did not usually exceed the symbol. (a) Paired testis weights of $15-64$-day-old hamsters. The level of significance is indicated by:

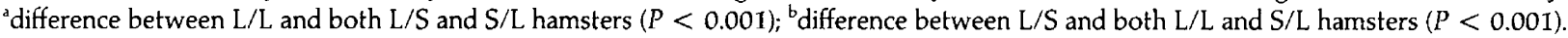
(b) Tubular diameters of 4-127-day-old hamsters. ${ }^{a}$ Difference between $\mathrm{S} / \mathrm{L}$ and both $\mathrm{L} / \mathrm{L}$ and $\mathrm{L} / \mathrm{S}$ hamsters $(P<0.001)$; ${ }^{b}$ difference between $\mathrm{L} / \mathrm{L}$ and $\mathrm{L} / \mathrm{S}$ hamsters $(P<0.01)$; 'difference between $\mathrm{L} / \mathrm{S}$ and both $\mathrm{L} / \mathrm{L}$ and $\mathrm{S} / \mathrm{L}$ hamsters $(P<0.001)$; ${ }^{\mathrm{d}}$ difference between $\mathrm{L} / \mathrm{L}$ and $S / L$ hamsters $(P<0.01)$.

(30 preleptotene nuclei per animal) was therefore used in Abercrombie's formula.

\section{The disector method}

The disector method (Sterio, 1984; Hardy et al., 1989; Mendis-Handagama et al., 1989) was applied to determine the total number of Sertoli cells per testis at 29 days. The embedded testis was completely sectioned. Every 100 sections, a pair of adjacent sections was collected. The total number of sections containing Sertoli cells was determined. Total testicular volume was calculated by multiplying the average area of the testis in the sections by the total number of sections containing Sertoli cells and by the measured section thickness. The average area of the testis was obtained by measuring the area of the testis every 100 sections with image analysis. L/S testes was sectioned at $1 \mu \mathrm{m}$ and $\mathrm{L} / \mathrm{L}$ and $\mathrm{S} / \mathrm{L}$ testes at $3 \mu \mathrm{m}$. Since $\mathrm{L} / \mathrm{S}$ testes were about one fifth of the size of $L / L$ and $S / L$ testes, the number of sections collected in the three groups was comparable. The section thickness was checked with a microscope that had been gauged with a cover-glass of known thickness. In the pairs of serial sections, Sertoli cells were counted by means of image analysis equipment, connected with a microscope and two monitors. First one section was recorded on one monitor, and then the same area was located on the serial section and recorded on the other monitor. In the first section, the Sertoli cell nuclei that did not appear in the second section were counted. Nuclei were only counted when they were completely inside a test frame on the monitor or when they touched the right or lower boundary of the frame. The area of the test frame multiplied by the section thickness gave the volume in which the nuclei were counted. In $\mathrm{L} / \mathrm{S}$ testes 30 and in $\mathrm{L} / \mathrm{L}$ and $\mathrm{S} / \mathrm{L}$ testes 60 areas were counted (always ten adjacent areas per pair of sections). Finally, the total number of Sertoli cells per testis was obtained by multiplying the number of Sertoli cell nuclei counted by the total testicular volume, divided by the volume in which the nuclei had been counted.

\section{Statistical analysis}

The labelling indexes of gonocytes and Sertoli cells and the mitotic index of gonocytes were transformed to arcscines to obtain a normal distribution of the data. The frequency of the most advanced cell types and the percentage of cross-sections containing a lumen were first divided by 100 to obtain a fraction which was then transformed to an arcsine. For the same purpose, a square root was extracted of the number of gonocytes per cross-section. Subsequently, data were analysed with the $t$ test modified according to Bonferroni (Fleiss, 1986). This means that the $P$ value has been divided by the number of comparisons made between the treatment groups. Differences were considered significant when $P<0.01$. Total numbers of Sertoli cells, testis weights, tubular diameters and the numbers of preleptotene spermatocytes were analysed with Bonferroni's $t$ test under the assumption of normality.

\section{Results}

\section{Body and testis weights}

Growth rates in the three experimental groups were similar from 4 to 29 days of age. At 43 days of age $L / S$ hamsters were significantly smaller $(P<0.01)$ than $\mathrm{L} / \mathrm{L}$ and $\mathrm{S} / \mathrm{L}$ hamsters. At 64 days, $L / S$ hamsters were also smaller but this difference was not significant. Body weights of $\mathrm{L} / \mathrm{L}$ and $\mathrm{S} / \mathrm{L}$ hamsters did not differ up to 64 days of age (data not shown).

Testis weights were measured from 15 to 64 days of age (Fig. 1a). At 15 days of age, testis weights in $\mathrm{L} / \mathrm{L}$ animals were significantly higher than in both $\mathrm{S} / \mathrm{L}$ and $\mathrm{L} / \mathrm{S}$ animals $(P<0.001)$. Testis weights in $\mathrm{L} / \mathrm{L}$ and $\mathrm{S} / \mathrm{L}$ hamsters increased up to 64 days 

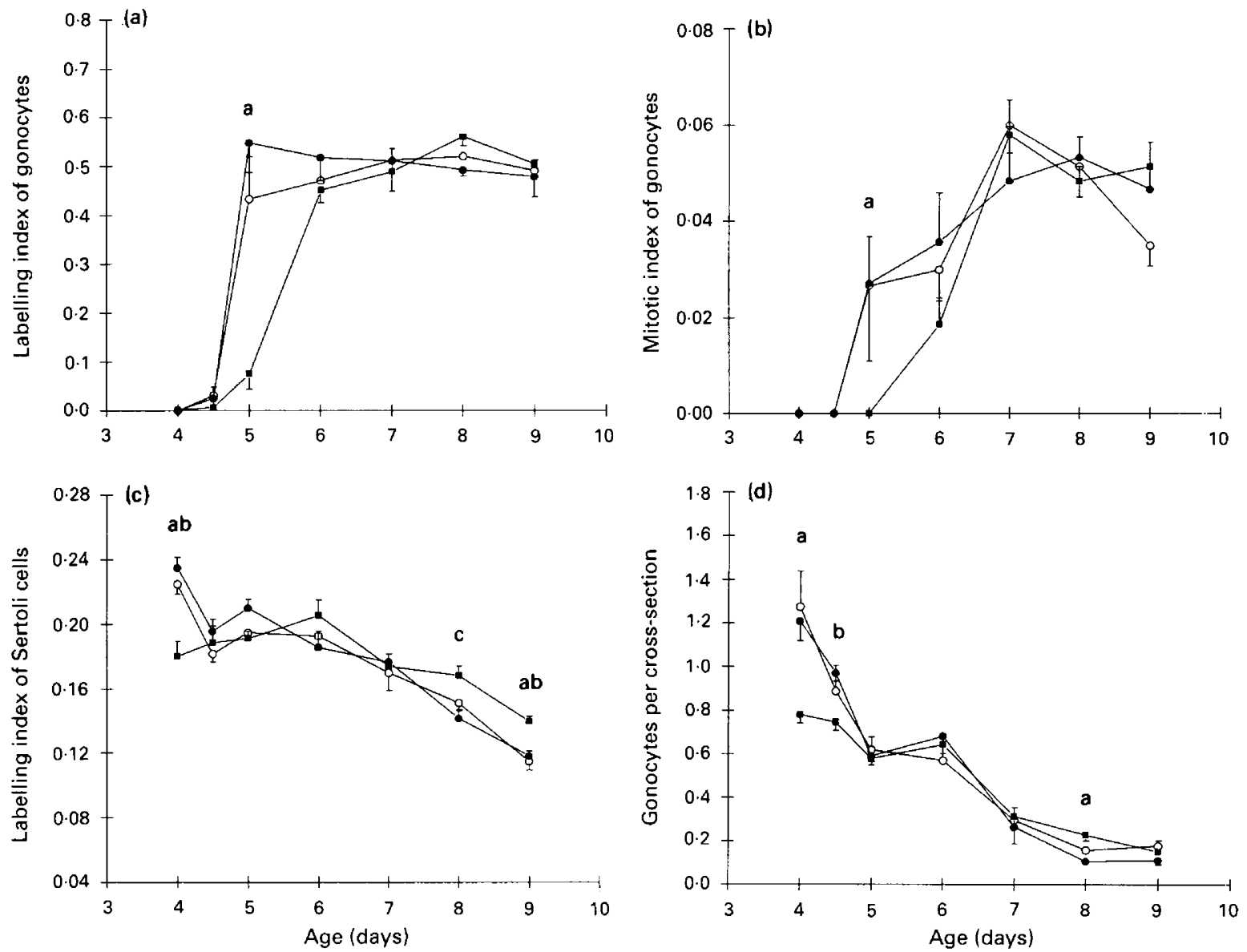

Fig. 2. Spermatogenic development in 4-9-day-old $(\mathrm{O}) \mathrm{L} / \mathrm{L}$,

$\mathrm{L} / \mathrm{S}$ and $(\boldsymbol{\square}) \mathrm{S} / \mathrm{L}$ hamsters $(n=4-8)$. The vertical bars represent the SEM. Sometimes the SEM did not exceed the symbol. (a) The BrdU labelling index of gonocytes. The level of significance is indicated by: ${ }^{a}$ difference between $\mathrm{S} / \mathrm{L}$ and both $\mathrm{L} / \mathrm{L}$ and $\mathrm{L} / \mathrm{S}$ hamsters $(P<0.001)$. (b) The mitotic index of gonocytes. ${ }^{\mathrm{a}} \mathrm{Difference}$ between $\mathrm{L} / \mathrm{S}$ and $\mathrm{S} / \mathrm{L}$ hamsters $(P<0.01)$. (c) The BrdU labelling index of Sertoli cells. ${ }^{2}$ Difference between $\mathrm{L} / \mathrm{L}$ and $\mathrm{S} / \mathrm{L}$ hamsters $(P<0.01)$; ${ }^{b}$ difference between $\mathrm{L} / \mathrm{S}$ and $\mathrm{S} / \mathrm{L}$ hamsters $(P<0.001)$; ${ }^{c}$ difference between $\mathrm{L} / \mathrm{S}$ and $\mathrm{S} / \mathrm{L}$ hamsters $(P<0.01)$. (d) The number of gonocytes per tubular cross-section. ${ }^{a}$ Difference between $\mathrm{L} / \mathrm{S}$ and $\mathrm{S} / \mathrm{L}$ hamsters $(P<0.01)$; ${ }^{b}$ difference between $\mathrm{L} / \mathrm{S}$ and $\mathrm{S} / \mathrm{L}$ hamsters $(P<0.001)$.

of age. From the age of 29 days testis weights in S/L hamsters were higher than in $\mathrm{L} / \mathrm{L}$ hamsters, but the differences were not significant. In hamsters reared under a short photoperiod, testis weights were reduced at all ages examined $(P<0.001)$.

\section{Tubular diameters}

At 15 days of age, tubular diameters in L/S animals were smaller than in L/L hamsters ( 80 versus $96 \mu \mathrm{m}, P<0.01$, Fig. $1 \mathrm{~b})$, indicating that the first influence of postnatal photoperiod can already be observed on day 15 . Tubular diameters in $\mathrm{L} / \mathrm{S}$ hamsters remained small up to 127 days of age. At 4 days, tubular diameters in $\mathrm{S} / \mathrm{L}$ hamsters were significantly smaller than in $L / L$ and $L / S$ animals $(43 \mu \mathrm{m}$ versus 48 and $50 \mu \mathrm{m}$ respectively; $P<0.001$ in both cases). From 8 to 43 days, tubular diameters did not differ between $\mathrm{S} / \mathrm{L}$ and $\mathrm{L} / \mathrm{L}$ animals. However, at 64 days, tubular diameters in $\mathrm{S} / \mathrm{L}$ hamsters were larger than in $\mathrm{L} / \mathrm{L}$ hamsters $(P<0.01)$.

\section{The onset of spermatogenesis}

In both $\mathrm{L} / \mathrm{L}$ and $\mathrm{L} / \mathrm{S}$ animals, the first gonocytes entered S-phase at 4.5 days of age, at which time in $\mathrm{L} / \mathrm{L}$ and in $\mathrm{L} / \mathrm{S}$ animals labelling indexes of 0.03 and 0.02 , respectively, were found (Fig. 2a). On day 5, the labelling index increased up to 0.43 in L/L hamsters and up to 0.55 in L/S hamsters (Fig. 3b). The labelling indexes of gonocytes in $\mathrm{L} / \mathrm{L}$ and $\mathrm{L} / \mathrm{S}$ hamsters did not differ at any of the ages examined.

In $S / L$ animals at 4.5 days of age, a labelling index of gonocytes of only 0.01 was found, while on day 5 the labelling index was 0.08 , which is significantly lower than in $L / L$ and L/S animals $(P<0.001)$. However, on day 6 , a labelling index comparable to that in $\mathrm{L} / \mathrm{L}$ and $\mathrm{L} / \mathrm{S}$ hamsters was found (about 0.50). These results indicate that, after prenatal exposure to short photoperiod, the majority of the gonocytes entered $\mathrm{S}$-phase at a later age. The first mitoses of gonocytes were observed on day 5 in both $\mathrm{L} / \mathrm{L}$ and $\mathrm{L} / \mathrm{S}$ animals. However, in $\mathrm{S} / \mathrm{L}$ animals the first mitoses of gonocytes were not observed 

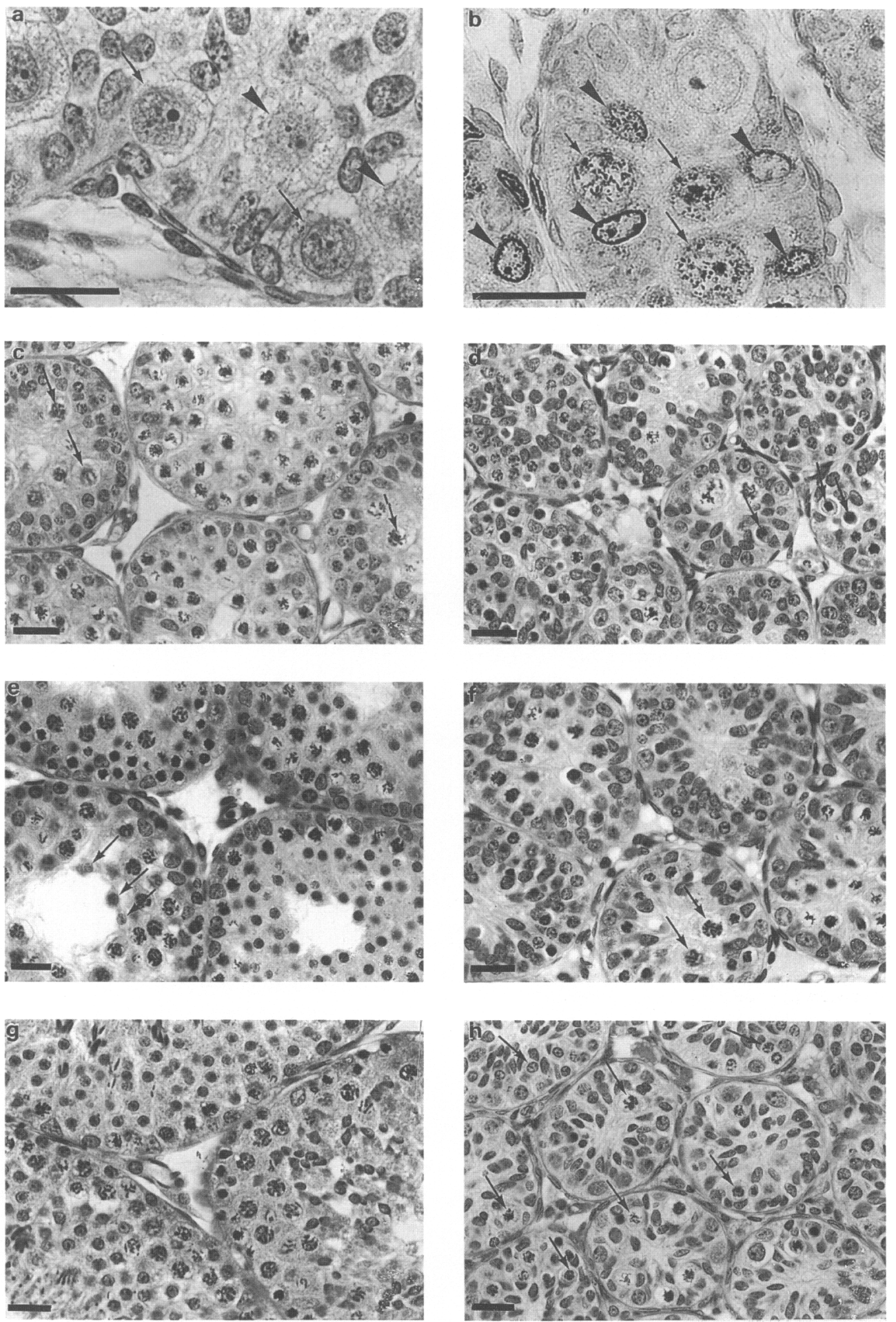

Fig. 3. Photographs of spermatogenic development in $\mathrm{L} / \mathrm{L}$ and $\mathrm{L} / \mathrm{S}$ hamsters. The bar represents $25 \mu \mathrm{m}$. (a) At 4 days of age gonocytes (arrows) are still in G1-arrest in both L/L and L/S (not shown) hamsters. Degenerating gonocytes (arrowheads) are often observed. (b) On day 5 some of the gonocytes (arrows) and Sertoli cells (arrowheads) in L/L (not shown) and L/S hamsters have incorporated BrdU. (c) In I5-day-old L/L hamsters, spermatogenesis has advanced up to late-pachytene spermatocytes (some indicated by arrows). (d) In 15-day-old L/S hamsters many degenerating spermatocytes are observed (some indicated by arrows). (e) At 22 days of age spermatogenesis in $\mathrm{L} / \mathrm{L}$ hamsters has advanced up to early stage VII round spermatids (arrows). (f) In 22-day-old L/S hamsters, spermatogenesis does not proceed beyond the late-pachytene stage (arrows). (g) At 64 days of age L/L animals show full spermatogenesis. (h) In L/S animals at 64 days of age most tubules contain up to mid-pachytene spermatocytes (some indicated by arrows). 
until day 6 (Fig. 2b), indicating that the start of spermatogenesis was delayed by one day by prenatal exposure to short photoperiod $(P<0.01)$ compared with $\mathrm{L} / \mathrm{S}$ hamsters.

\section{Sertoli cells}

Labelled Sertoli cells were found at all ages between day 4 and day 9 (Fig. $2 \mathrm{c}$ and 3 b). The labelling indexes of Sertoli cells in $\mathrm{L} / \mathrm{L}$ and $\mathrm{L} / \mathrm{S}$ hamsters did not differ. However, at 4 days, the labelling index of Sertoli cells in S/L hamsters was significantly lower than in both $\mathrm{L} / \mathrm{L}(P<0.01)$ and $\mathrm{L} / \mathrm{S}$ hamsters $(P<0.001)$. At 8 days, it was significantly higher than in $\mathrm{L} / \mathrm{S}$ hamsters $(P<0.01)$, and at 9 days it was higher than in both $\mathrm{L} / \mathrm{L}(P<0.01)$ and $\mathrm{L} / \mathrm{S}$ hamsters $(P<0.001)$. These results indicate that at first Sertoli cell proliferation was slowed down by prenatal exposure to short photoperiod, and that later the decrease in proliferative activity was also delayed.

Up to 15 days of age, Sertoli cells displayed an immature morphology (a round or elongated nucleus with several, small nucleoli) in the three treatment groups. In 22-day-old L/L and $\mathrm{S} / \mathrm{L}$ hamsters most Sertoli cells contained a mature nucleus (a rounded, indentated nucleus and a large nucleolus with two satellites). From 29 days onwards, all Sertoli cells in L/L and $\mathrm{S} / \mathrm{L}$ hamsters were morphologically mature. Sertoli cells of L/S hamsters of 22 days of age usually contained one nucleolus with two satellites, but their nuclei and nucleoli were smaller than those of hamsters raised under long photoperiod. From 29 days onwards, Sertoli cell nuclei in L/S animals had a mature morphology, but they remained small and became irregularly shaped.

Sertoli cell maturation, as evidenced by the formation of a tubular lumen, was retarded in the $\mathrm{L} / \mathrm{S}$ and $\mathrm{S} / \mathrm{L}$ animals at 15 days of age compared with $\mathrm{L} / \mathrm{L}$ animals. In $\mathrm{L} / \mathrm{L}$ animals at this age, $46 \pm 10 \%$ (mean \pm SEM) of the tubular cross-sections studied showed a lumen, whereas in L/S animals only $14 \pm 6 \%$ and in $S / L$ animals $10 \pm 9 \%$ of the cross-sections contained a lumen. However, these differences were not significant. From 22 days of age onwards, a clear lumen had developed in all tubules of $\mathrm{L} / \mathrm{L}$ and $\mathrm{S} / \mathrm{L}$ hamsters. A tubular lumen was not observed in the L/S animals from 22 days onwards, except in two of seven animals, at 127 days, which exhibited spontaneous recrudescence of spermatogenesis.

\section{Cell types in the developing testis}

At 4 days of age, gonocytes were still in G1-arrest and located in the centre of the tubules (Fig. 3a). These gonocytes were large round cells with a spherical nucleus, dispersed chromatin and several (1-3) prominent nucleoli. At 4.5 days of age, some gonocytes were characterized by an enlarged nucleus, granular chromatin, small nucleoli and abundant cytoplasm.

Between 4 and 5 days of age, the number of gonocytes per tubular cross-section decreased (Fig. 2d), probably owing to both Sertoli cell proliferation causing a lengthening of the tubules (Fig. 2c) and degeneration of gonocytes, which was observed particularly on day 4 and day 4.5 . From day 5 onwards, gonocytes divided and formed A spermatogonia and in this way the numbers of gonocytes also decreased further.
No differences were seen between the numbers of gonocytes per cross-section in $\mathrm{L} / \mathrm{L}$ and $\mathrm{L} / \mathrm{S}$ hamsters.

In $\mathrm{S} / \mathrm{L}$ hamsters the number of gonocytes per cross-section at 4 and at 4.5 days was lower than in L/S hamsters $(0.78$ versus $1.21, P<0.01$ and 0.75 versus $0.97, P<0.001$, respectively). Apparently, the prenatal short photoperiod affects the number of gonocytes.

In both $\mathrm{L} / \mathrm{L}$ and $\mathrm{L} / \mathrm{S}$ animals the first $\mathrm{A}$ spermatogonia were observed on day 6 and the first Intermediate and B spermatogonia on days 8 and 9 , respectively. In $S / L$ animals the first $A$ and Intermediate spermatogonia appeared on days 7 and 9 , respectively.

The further testicular development was studied by determining the frequency of the most advanced cell types in 8-to 127-day-old animals (Table 1 ). Under long photoperiod, spermatogenesis advanced up to late-pachytene stage at 15 days (Fig. 3c), up to round spermatids in early stage VII at 22 days (Fig. 3e), and up to elongated spermatids in early stage VII at 29 days. From 43 days onwards full spermatogenesis was observed in $\mathrm{L} / \mathrm{L}$ animals (Fig. 3g: L/L animals at 64 days).

Under short photoperiod, spermatogenesis advanced up to late-pachytene stage at 15 days of age. At this age many degenerating spermatocytes were observed (Fig. $3 \mathrm{~d}$ ). In the 22-127-day-old animals spermatogenesis was arrested mainly at the mid-pachytene stage (Fig. 3f, h). Degenerating spermatogonia were sometimes observed, but the most extensive degeneration took place during the preleptotene, leptotene, zygotene and pachytene stage. The few round spermatids observed were always degenerating. At 22 days, spermatogenesis in L/S animals was significantly less advanced than in $\mathrm{L} / \mathrm{L}$ and $\mathrm{S} / \mathrm{L}$ animals. At this age, $\mathrm{L} / \mathrm{S}$ animals contained more cross-sections with spermatogonia $(P<0.01)$ compared with $\mathrm{L} / \mathrm{L}$ and $\mathrm{S} / \mathrm{L}$ hamsters and more cross-sections with up to mid-pachytene spermatocytes $(P<0.01)$ compared with $\mathrm{L} / \mathrm{L}$ animals, and less cross-sections with late-pachytene spermatocytes $(P<0.001)$ compared with $\mathrm{S} / \mathrm{L}$ animals. From 29 up to 64 days of age, all values for L/S animals differed from both $\mathrm{L} / \mathrm{L}$ and $\mathrm{S} / \mathrm{L}$ animals $(P<0.001)$, except for the values of the late-pachytene spermatocytes at 29 days of age, which did not differ. Spermatogenesis remained regressed in L/S animals until 127 days, when two out of seven animals exhibited spontaneous recrudescence of spermatogenesis, with values resembling those of $\mathrm{L} / \mathrm{L}$ hamsters.

At 43 days of age $\mathrm{S} / \mathrm{L}$ hamsters contained more cross-sections with round spermatids and less cross-sections with elongated spermatids than did $\mathrm{L} / \mathrm{L}$ animals $(P<0.001$ for both round and elongated spermatids).

\section{Numbers of preleptotene spermatocytes}

Preleptotene spermatocytes were first counted at 15 days of age (Fig. 4). The numbers of preleptotene spermatocytes expressed per 1000 Sertoli cell nucleoli increased gradually in $\mathrm{L} / \mathrm{L}$ hamsters up to 43 days. From 22 days onwards, the values in $\mathrm{L} / \mathrm{S}$ hamsters were reduced compared with both $\mathrm{L} / \mathrm{L}$ and $\mathrm{S} / \mathrm{L}$ hamsters $(P<0.001$ in all cases). The numbers of preleptotene spermatocytes in L/S hamsters remained low except in two out of seven animals at 127 days, which showed values comparable to $\mathrm{L} / \mathrm{L}$ animals. Prenatal exposure to short photoperiod did not significantly alter the numbers of preleptotene spermatocytes 
Table 1. Frequency (mean $\pm \mathrm{SEM}$ ) of the most advanced cell types in tubular cross-sections of $\mathrm{L} / \mathrm{L}, \mathrm{L} / \mathrm{S}$ and $\mathrm{S} / \mathrm{L}$ hamsters from 8 to 127 days of age

\begin{tabular}{|c|c|c|c|c|c|}
\hline Animals ( $n$ ) & Spermatogonia & M-Pach & L-Pach & R Spt & E Spt \\
\hline $8 \mathrm{~d} \mathrm{L/L}(7)$ & 100 & 0 & 0 & 0 & 0 \\
\hline $15 \mathrm{~d} \mathrm{~L} / \mathrm{L}(8)$ & $2 \pm 1$ & $82 \pm 3$ & $15 \pm 4$ & 0 & 0 \\
\hline $22 \mathrm{~d} \mathrm{~L} / \mathrm{L}(11)$ & $\overline{0}$ & $6 \pm 1$ & $37 \pm 3$ & $57 \pm 4$ & 0 \\
\hline $29 \mathrm{~d} \mathrm{~L} / \mathrm{L}(6)$ & 0 & $\overline{0}$ & $8 \pm 5$ & $62 \pm 6$ & $30 \pm$ \\
\hline $43 \mathrm{~d} L / L(5)$ & 0 & 0 & $\overline{0}$ & $5 \pm 1$ & $95 \pm$ \\
\hline $64 \mathrm{~d} L / L(9)$ & 0 & 0 & 0 & $5 \pm 1$ & $95 \pm$ \\
\hline $8 \mathrm{~d} L / \mathrm{S}(6)$ & 100 & 0 & 0 & 0 & 0 \\
\hline $15 \mathrm{~d} L / S(8)$ & $9 \pm 3$ & $85 \pm 2$ & $7 \pm 2$ & 0 & 0 \\
\hline $22 \mathrm{~d} L / S(6)^{\mathrm{a}}$ & $54 \pm 13$ & $34 \pm 7$ & $12 \pm 8$ & 0 & 0 \\
\hline $29 \mathrm{~d} \mathrm{~L} / \mathrm{S}(7)^{\mathrm{a}}$ & $38 \pm 9$ & $57 \pm 8$ & $5 \pm 1$ & 0 & 0 \\
\hline $43 \mathrm{~d} \mathrm{~L} / \mathrm{S}(5)^{\mathrm{a}}$ & $27 \pm 7$ & $67 \pm 6$ & $6 \pm 2$ & 0 & 0 \\
\hline $64 \mathrm{~d} L / S(5)^{2}$ & $30 \pm 8$ & $65 \pm 7$ & $5 \pm 2$ & 0 & 0 \\
\hline $85 \mathrm{~d} L / \mathrm{S}(9)$ & $36 \pm 3$ & $60 \pm 3$ & $4 \pm 1$ & 0 & 0 \\
\hline $106 \mathrm{~d}$ L/S (6) & $40 \pm 5$ & $57 \pm 4$ & $3 \pm 1$ & 0 & 0 \\
\hline $127 \mathrm{~d} \mathrm{~L} / \mathrm{S}(7)$ & $31 \pm 8$ & $51 \pm 9$ & $3 \pm 3$ & $1 \pm 1$ & $13 \pm 1$ \\
\hline $8 \mathrm{~d} S / L(6)$ & 100 & 0 & 0 & 0 & 0 \\
\hline $15 \mathrm{~d} S / L(4)$ & $1 \pm 1$ & $87 \pm 2$ & $12 \pm 3$ & 0 & 0 \\
\hline $22 \mathrm{~d} S / L$ & $\overline{0}$ & $29 \pm 16$ & $41 \pm 6$ & $30 \pm 13$ & 0 \\
\hline $29 \mathrm{~d} S / L(7)$ & 0 & $\overline{0}$ & $3 \pm 2$ & $75 \pm 5$ & $22 \pm$ \\
\hline $43 \mathrm{~d} S / L(7)^{b}$ & 0 & 0 & 0 & $15 \pm 1$ & $85 \pm$ \\
\hline $64 \mathrm{~d} \mathrm{S/L} \mathrm{(4)}$ & 0 & 0 & 0 & $8 \pm 2$ & $92 \pm$ \\
\hline
\end{tabular}

L/L: long photoperiod before and after birth; L/S: long photoperiod before and short photoperiod after birth; S/L: short photoperiod before and long photoperiod after birth; M-Pach: preleptotene spermatocytes up to pachytene spermatocytes associated with B spermatogonia; L-Pach: pachytene spermatocytes associated with preleptotene spermatocytes up to pachytene spermatocytes associated with zygotene spermatocytes; R Spt: from meiosis up to stage XII round spermatids; E Spt: from stage I elongated spermatids onwards. ${ }^{2}$ Differences between $\mathrm{L} / \mathrm{S}$ and both $\mathrm{L} / \mathrm{L}$ and $\mathrm{S} / \mathrm{L}$ animals are: $22 \mathrm{~d} \mathrm{~L} / \mathrm{S}$ spermatogonia $P<0.01$ compared with $\mathrm{L} / \mathrm{L}$ and $\mathrm{S} / \mathrm{L}$ animals; $22 \mathrm{~d} \mathrm{~L} / \mathrm{S} \mathrm{M}-\mathrm{Pach} P<0.01$ compared with L/L animals; $22 \mathrm{~d} \mathrm{~L} / \mathrm{S} \mathrm{L}-\mathrm{Pach} P<0.001$ compared with S/L animals; $29-64 \mathrm{~d}$ all values of $\mathrm{L} / \mathrm{S}$ animals differed from both $\mathrm{L} / \mathrm{L}$ and $\mathrm{S} / \mathrm{L}$ values with $P<0.001$, except the $29 \mathrm{~d} \mathrm{~L}-\mathrm{Pach}$ of $\mathrm{L} / \mathrm{S}$ animals which did not differ from $\mathrm{L} / \mathrm{L}$ or $\mathrm{S} / \mathrm{L}$ L-Pach. ${ }^{\circ}$ Difference between $\mathrm{S} / \mathrm{L}$ and $\mathrm{L} / \mathrm{L}$ animals $(P<0.001)$ for both round and elongated spermatids.

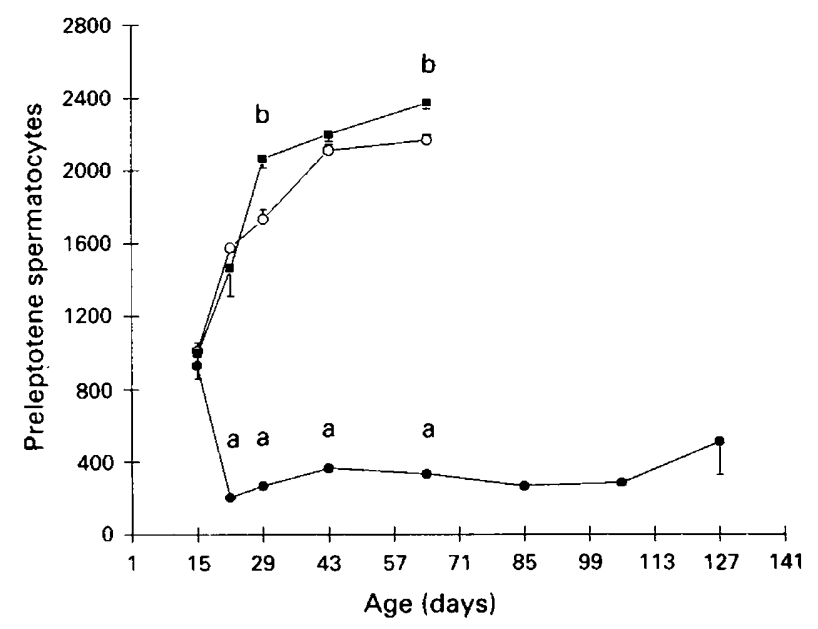

Fig. 4. Numbers of preleptotene spermatocytes expressed per 1000 Sertoli cell nucleoli in 15-127-day-old (O) L/L, (O) L/S and (ם) S/L hamsters $(n=4-11)$. The vertical bars represent the SEM. The SEM did not usually exceed the symbol. The level of significance is indicated by: adifference between $\mathrm{L} / \mathrm{S}$ and both $\mathrm{L} / \mathrm{L}$ and $\mathrm{S} / \mathrm{L}$ hamsters $(P<0.001)$; bdifference between $\mathrm{L} / \mathrm{L}$ and $\mathrm{S} / \mathrm{L}$ hamsters $(P<0.001)$.

up to 22 days compared with $\mathrm{L} / \mathrm{L}$ animals. However, at 29 and at 64 days, S/L hamsters contained significantly higher numbers of preleptotene spermatocytes $(P<0.001)$.

\section{Numbers of Sertoli cells per testis}

Total Sertoli cell numbers per testis were determined at 29 days of age in $\mathrm{L} / \mathrm{L}, \mathrm{L} / \mathrm{S}$ and $\mathrm{S} / \mathrm{L}$ hamsters. In $\mathrm{L} / \mathrm{L}$ hamsters, $1.38 \times 10^{7}\left( \pm 0.16 \times 10^{7}\right)$ Sertoli cells were found, whereas $\mathrm{L} / \mathrm{S}$ hamsters contained $1.14 \times 10^{7}\left( \pm 0.06 \times 10^{7}\right)$ and $\mathrm{S} / \mathrm{L}$ hamsters contained $1.14 \times 10^{7}\left( \pm 0.13 \times 10^{7}\right)$ Sertoli cells (mean $\pm \mathrm{SEM}$ ). These values did not differ significantly, indicating that pre- and postnatal daylength did not influence the final number of Sertoli cells per testis.

\section{Discussion}

In $\mathrm{L} / \mathrm{L}$ Djungarian hamsters, gestated and reared under long photoperiod, spermatogenesis appeared to be initiated 4.5 days after birth. At that time the first labelled gonocytes were present. On day 5 almost half of the gonocytes were in S-phase. From day 5, gonocytes entered mitosis and formed A spermatogonia, which were first observed on day 6. Full spermatogenesis was observed from 43 days. The proliferative activity of the Sertoli cells was high on day 4 and then gradually decreased.

In L/S hamsters, gestated under long photoperiod and reared from birth under short photoperiod, the start of spermatogenesis did not differ from that in L/L hamsters. Hence, the duration of the postnatal photoperiod did not affect the onset of spermatogenesis, as had been suggested by Hoffmann (1978). Up to 9 
days of age, the further advancement of spermatogenesis did not differ from that in $\mathrm{L} / \mathrm{L}$ animals. Spermatogenesis in L/S animals advanced up to the late-pachytene stage at 15 days of age, but it did not proceed beyond this stage in older animals. Our results show that the first effect of the postnatal photoperiod is already visible at 15 days of age, when testis weights and tubular diameters were significantly reduced in L/S hamsters. From 22 days onwards, the number of preleptotene spermatocytes was also reduced in L/S hamsters. Spermatogenesis was arrested mainly at the mid-pachytene level, and no tubular lumen was formed. The formation of Sertoli cells was not significantly affected by the postnatal photoperiod, as the number of Sertoli cells per testis was comparable to that in the testes of $\mathrm{L} / \mathrm{L}$ and $\mathrm{S} / \mathrm{L}$ hamsters. Sertoli cells in $\mathrm{L} / \mathrm{S}$ hamsters attained a mature morphology at 22 days as did Sertoli cells in $\mathrm{L} / \mathrm{L}$ and $\mathrm{S} / \mathrm{L}$ hamsters, but they remained small thereafter.

Yellon and Goldman (1984), and Pratt and Goldman (1986) did not observe a difference in testis weight between Djungarian hamsters reared under long or short photoperiod at 15 days of age. However, these authors used a short photoperiod of $10 \mathrm{~h}$ light:14 $\mathrm{h}$ dark, whereas in our experiment $\mathrm{L} / \mathrm{S}$ hamsters were kept at $4 \mathrm{~h}$ light:20 h dark, which could give a more profound effect. The effect of photoperiod on spermatogenesis in Djungarian hamsters is mediated by the pineal gland which secretes melatonin during the night (Brackmann, 1977; Brackmann and Hoffmann, 1977). It has been shown that the pineal gland in Djungarian hamsters is innervated by 15 days of age (Van Veen et al., 1978) and that a day-night difference in pineal melatonin content is also present at this age (Tamarkin et al., 1980; Yellon et al., 1985). The reduced spermatogenic development in the 15-day-old L/S hamsters could therefore be mediated by melatonin secreted by the pineal gland of the pup. However, it is also possible that maternal melatonin transported in milk conveys photoperiodic information to the pups. Administration of $\left[{ }^{3} \mathrm{H}\right]$ melatonin to lactating rats is rapidly transferred to the pups (Reppert and Klein, 1978). In addition, it has been shown that serum melatonin concentrations in 10-day-old rats depend on maternal melatonin transfer (Velázquez et al., 1992).

Melatonin probably affects postnatal spermatogenic development through alterations in gonadotrophin concentrations. Short photoperiod or melatonin administration during long photoperiod have been shown to suppress follicle-stimulating hormone, luteinizing hormone and prolactin concentrations in the developing Djungarian hamster (Yellon and Goldman, 1984; Carter and Goldman, 1983; Goldman et al., 1984).

Spermatogenesis in hamsters reared under short photoperiod advanced up to the late-pachytene stage at 15 days of age, but did not proceed beyond this stage in older animals. Although spermatocytes were formed in these animals, these cells could be seen to degenerate at the preleptotene, leptotene, zygotene and pachytene stages. Very few spermatocytes could complete meiotic divisions and the rare spermatids formed degenerated quickly. In this respect, the juvenile Djungarian hamster is comparable to the white-footed mouse, which shows tubules containing spermatogonia and early spermatocytes at 25 days of age (Johnston and Zucker, 1980). The fast response in juvenile Djungarian hamsters clearly differs from that in pubertal golden hamsters, which does not respond to the length of the photoperiod until 6 weeks of age (Gaston and Menaker, 1967).
In adult animals the regression of spermatogenesis during the nonbreeding season varies among photoperiodic species. Spermatogenesis remains complete, but daily sperm production or the number of spermatids is reduced in for example Soay rams (Hochereau-de Reviers et al., 1985), stallions (Johnson and Thompson, 1983), red deer (Hochereau-de Reviers and Lincoln, 1978), European hamsters (Reznik-Schüller and Reznik, 1973), and meadow voles (Dark et al., 1983). In other species for example Australian bush rats (Hodgson et al., 1979) and rock hyraxes (Neaves, 1973) spermatogenesis is regressed at the level of round spermatids. In white-footed mice (Johnston and Zucker, 1980) and adult golden hamsters (Gaston and Menaker, 1967), spermatogenesis does not proceed beyond the spermatocyte stage. Adult Djungarian hamsters apparently belongs to the latter category.

Our results clearly show that a short photoperiod before birth affects both early and late testicular development after birth. On day 4 and 4.5 , the number of gonocytes per tubular cross-section was reduced in $\mathrm{S} / \mathrm{L}$ hamsters, and gonocyte proliferation was strongly reduced on day 5 , resulting in a delay of the start of spermatogenesis by one day. Sertoli cell proliferation was also shifted to later ages. The late effects consisted of smaller numbers of tubular cross-sections with the most advanced cell type, higher numbers of preleptotene spermatocytes, and larger tubular diameters in $\mathrm{S} / \mathrm{L}$ than in $\mathrm{L} / \mathrm{L}$ testes. Testicular weights also tended to be higher in S/L animals. However, the total number of Sertoli cells per testis was not affected by prenatal short photoperiod. Apparently, the decreased proliferation of Sertoli cells shortly after birth was compensated for by a slower cessation of Sertoli cell proliferation at later ages.

An important question is whether the delayed initiation of spermatogenesis in S/L hamsters can be explained in terms of changes in hormone concentrations caused by prenatal exposure to short photoperiod. Both the proliferation of gonocytes in the neonatal rat (Almirón and Chemes, 1988) and the proliferation of Sertoli cells in the fetal and neonatal rat (Almirón and Chemes, 1988; Orth, 1984; Orth and Boehm, 1990) were shown to be stimulated by FSH. As in the developing Djungarian hamster short photoperiod suppresses FSH concentrations (Yellon and Goldman, 1984; Carter and Goldman, 1983; Goldman et al., 1984), the low FSH concentrations may be the cause of the delay in both the start of spermatogenesis and the peak in Sertoli cell proliferation. Hence, maternal melatonin may affect testicular development through an alteration in the FSH concentrations of the pup during the prenatal period.

In $\mathrm{S} / \mathrm{L}$ animals, the most advanced spermatogenic cells tended to be less developed than in $\mathrm{L} / \mathrm{L}$ animals. The difference was significant at 43 days of age. The cause of this phenomenon is not clear but several factors may play a role. First, there is a delay in the active proliferation of gonocytes but, as this is only one day, this will not be an important factor. Furthermore, after birth, the number of gonocytes was found to be smaller in S/L animals. As after irradiation, low numbers of spermatogonial stem cells could lead to enhanced self-renewal of stem cells (Van Beek et al., 1986) and consequently a reduction in the number of differentiating cells formed; this could also be a cause for the delay in spermatogenic development. Finally, there was a delay in Sertoli cell proliferation probably resulting in a delayed 
maturation of these cells, which may lead to a reduced capacity to support spermatogenic cells for some time.

Surprisingly, from 29 days onwards the number of preleptotene spermatocytes per Sertoli cell was increased, and, at 64 days, an increased tubular diameter was found in $S / L$ animals. These results indicate that, in adult S/L animals, Sertoli cells could support more germinal cells. Stetson et al. (1986) showed that prenatal exposure to short photoperiod increased testis weights on days 28 and 34, when hamsters were reared under long photoperiod. As our results show that the number of Sertoli cells per testis does not increase in $S / L$ animals, this cannot be the cause of the increased testis weights. The increased testis weight in these animals will rather be due to the increase in the numbers of germinal cells per Sertoli cell. This is an interesting phenomenon that requires further study.

We wish to thank H. J. G. van de Kant for skilful technical assistance, R. P. F. A. Vergouwen for helpful discussions, I. van der Tweel for her advice about statistical procedures, and A. N. van Rijn and R. Scriwanek for preparing the photographs.

\section{References}

Abercrombie M (1946) Estimation of nuclear population from microtome sections Anatomical Record 94 239-247

Almirón I and Chemes H (1988) Spermatogenic onset. II. FSH modulates mitotic activity of germ and Sertoli cells in immature rats Intermational Joumal of Andrology 11 235-246

Brackmann M (1977) Melatonin delays puberty in the Djungarian hamster Naturwissenschaften $64642-643$

Brackmann M and Hoffmann K (1977) Pinealectomy and photoperiod influence testicular development in the Djungarian hamster Naturwissenschaften 64 341

Carter DS and Goldman BD (1983) Progonadal role of the pineal in the Djungarian hamster (Phodopus sungorus sungorus): mediation by melatonin Endocrinology 113 1268-1273

Chowdhury AK and Steinberger $\mathbf{E}$ (1975) Effect of $5 \alpha$ reduced androgens on sex accessory organs, initiation and maintenance of spermatogenesis in the rat Biology of Reproduction 12 609-617

Dark J, Zucker I and Wade GN (1983) Photoperiodic regulation of body mass, food intake, and reproduction in meadow voles American Journal of Physiology 245 R334-R338

Figala J, Hoffmann K and Goldau G (1973) Zur Jahresperiodik beim Dsungarischen Zwerghamster Phodopus sungorus Pallas Oecologia 12 89-118

Fleiss JL (1986) In The Design and Analysis of Clinical Experiments, pp 104-105 Eds V Barnett, RA Bradley, JS Hunter, DG Kendall, RG Miller Jr, SM Stigler and GS Watson. HY Wiley, New York

Gaston S and Menaker M (1967) Photoperiodic control of hamster testis Science $158925-928$

Goldman BD, Darrow JM and Yogev L (1984) Effects of timed melatonin infusions on reproductive development in the Djungarian hamster (Phodopus sungorus) Endocrinology 114 2074 -2083

Hardy MP, Zirkin BR and Ewing LL (1989) Kinetic studies on the development of the adult population of Leydig cells in testes of the pubertal rat Endocrinology $124762-770$

Harms G, Van Goor H, Koudstraal J, De Ley L and Hardonk MJ (1986) Immunohistochemical demonstration of DNA-incorporated 5-bromodeoxyuridine in frozen and plastic embedded sections Histochemistry 85 139-143

Hilscher W and Makoski HB (1968) Histologische und autoradiographische Untersuchungen zur "Präspermatogenese" und "Spermatogenese" der Ratte Zeitschrift für Zellforschung 86 327-350

Hochereau-de Reviers MT and Lincoln GA (1978) Seasonal variation in the histology of the testis of the red deer. Cerous elaphus Joumal of Reproduction and Fertility 54 209-213

Hochereau-de Reviers MT, Perreau C and Lincoln GA (1985) Photoperiodic variations of somatic and germ cell populations in the Soay ram testis Journal of Reproduction and Fertility $\mathbf{7 4}$ 329-334
Hodgson YM, Irby DC, Kerr JB and de Kretser DM (1979) Studies on the structure and function of the Sertoli cells in a seasonally breeding rodent Biology of Reproduction 21 1091-1098

Hoffmann K (1973) The influence of photoperiod and melatonin on testis size, body weight, and pelage colour in the Djungarian hamster (Phodopus sungorus) Joumal of Comparative Physiology 85 267-282

Hoffmann K (1978) Effects of short photoperiods on puberty, growth and moult in the Djungarian hamster (Phodopus sungorus) journal of Reproduction and Fertility $54 \quad 29-35$

Horton TH, Ray SL and Stetson MH (1989) Maternal transfer of photoperiodic information in Siberian hamsters. III. Melatonin injections program postnatal reproductive development expressed in constant light Biology of Reproduction $4134-39$

Johnson L and Thompson DL, Jr (1983) Age-related and seasonal variation in the Sertoli cell population, daily sperm production and serum concentrations of follicle-stimulating hormone, luteinizing hormone and testosterone in stallions Biology of Reproduction 29 777-789

Johnston PG and Zucker I (1980) Photoperiodic regulation of reproductive development in white-footed mice (Peromyscus leucopus) Biology of Reproduction $22983-989$

Kluin PhM and De Rooij DG (1981) A comparison between the morphology and cell kinetics of gonocytes and adult type undifferentiated spermatogonia in the mouse International Joumal of Andrology 4 475-493

Mendis-Handagama SLMC, Keeney DS, Hardy MP and Ewing LL (1989) Application of the disector method to enumerate cells in the testis Annals of the New York Academy of Sciences 564 86-98

Miething A (1989) Morphological studies on prespermatogonia and pre-Sertoli cells in the testes of 6- to 11-day-old golden hamsters Anatomy and Embryology 179 503-510

Neaves WB (1973) Changes in testicular Leydig cells and in plasma testosterone levels among seasonally breeding rock hyrax Biology of Reproduction 8 451-466

Orth JM (1984) The role of follicle-stimulating hormone in controlling Sertoli cell proliferation in testes of fetal rats Endocrinology 115 1248-1255

Orth JM and Boehm R (1990) Endorphin suppresses FSH-stimulated proliferation of isolated neonatal Sertoli cells by a pertussis toxin-sensitive mechanism Anatomical Record 226 320-327

Oud JL and De Rooij DG (1977) Spermatogenesis in the Chinese hamster Anatomical Record 187 113-124

Pratt BL and Goldman BD (1986) Maternal influence on activity rhythms and reproductive development in Djungarian hamster pups Biology of Reproduction $34655-663$

Reppert SM and Klein DC (1978) Transport of maternal [ $\left.{ }^{3} \mathrm{H}\right]$ melatonin to suckling rats and the fate of $\left[{ }^{3} \mathrm{H}\right]$ melatonin in the neonatal rat Endocrinology $102582-588$

Reznik-Schüller H and Reznik G (1973) Comparative histometric investigations of the testicular function of European hamsters (Cricetus cricetus) with and without hibernation Fertility and Sterility 24 698-705

Sapsford CS (1962) Changes in the cells of the sex cords and seminiferous tubules during the development of the testis of the rat and the mouse Australian Journal of Zoology 10 178-191

Steinberger A (1967) Relationship between the yield of spermatocytes in rat testes organ culture and age of the donor animal Anatomical Record 157 327 (Abstract)

Steinberger E and Duckett GE (1965) Effect of estrogen or testosterone on initiation and maintenance of spermatogenesis in the rat Endocrinology 76 $1184-1189$

Sterio DC (1984) The unbiased estimation of number and sizes of arbitrary particles using the disector Journal of Microscopy 134 127-136

Stetson MH, Elliott JA and Goldman BD (1986) Maternal transfer of photoperiodic information influences the photoperiodic response of prepubertal Djungarian hamsters (Phodopus sungorus sungorus) Biology of Reproduction 34 664-669

Stetson MH, Ray SL, Creyaufmiller N and Horton TH (1989) Maternal transfer of photoperiodic information in Siberian hamsters II: The nature of the maternal signal, time of signal transfer and the effect of the maternal signal on peripubertal reproductive development in the absence of photoperiodic input Biology of Reproduction 40 458-465

Tamarkin L, Reppert SM, Orloff DJ, Klein DC, Yellon SM and Goldman BD (1980) Ontogeny of the pineal melatonin rhythm in the Syrian (Mesocricetus auratus) and Siberian (Phodopus sungorus) hamsters and in the rat Endocrinology 107 1061-1064 
Van Beek MEAB, Davids JAG and De Rooij DG (1986) Nonrandom distribution of mouse spermatogonial stem cells surviving fission neutron irradiation Radiation Research 107 11-23

Van de Kant HJG, Van Pelt AMM, Vergouwen RPFA and De Rooij DG (1990) A rapid immunogold-silver staining for detection of bromodeoxyuridine in large numbers of plastic sections, using microwave irradiation Histochemical Journal 22 321-326

Van Goor H, Harms G, Gerrits PO, Kroese FGM, Poppema S and Grond J (1988) Immunohistochemical antigen demonstration in plastic-embedded lymphoid tissue Joumal of Histochemistry and Cytochemistry 36 115-120

Van Veen Th, Brackmann M and Moghimzadeh E (1978) Post-natal development of the pineal organ in the hamsters Phodopus sungorus and Mesocricetus auratus Cell and Tissue Research 189 241-250
Velázquez E, Esquifino AI, Zueco JA, Albusac JMR and Blázquez E (1992) Evidence that circadian variations of circulating melatonin levels in fetal and suckling rats are dependent on maternal melatonin transfer Neuroendocrinology $55 \quad 321-326$

Weaver DR and Reppert SM (1986) Maternal melatonin communicates day length to the fetus in Djungarian hamsters Endocrinology $1192861-2863$

Yellon SM and Goldman BD (1984) Photoperiod control of reproductive development in the male Djungarian hamster (Phodopus sungorus) Endocrinology $114664-670$

Yellon SM, Tamarkin L and Goldman BD (1985) Maturation of the pineal melatonin rhythm in long- and short-day reared Djungarian hamsters Experientia $41651-652$ 